\title{
Opkomst oncologisch bevolkingsonderzoek kan beter
}

Thom Bongaerts

De opkomstcijfers van de oncologische bevolkingsonderzoeken (BVO’s) in de grote steden behoren tot de laagste van Nederland. De grote diversiteit in sociaal-economische en culturele achtergronden van de inwoners speelt hierbij vermoedelijk een rol. Nieuw onderzoek in Den Haag richt zich op de oorzaken en verklaringen van deze verschillen en op de optimalisatie van de bevolkingsonderzoeken.

Er zijn drie oncologische BVO's in Nederland: de screeningsonderzoeken naar borst-, baarmoederhals- en darmkanker. Recente onderzoeken laten zien dat lage deelname aan screening afhangt van veel verschillende factoren, maar met name voorkomt bij lage SES-groepen, niet-westerse migranten en inwoners van stedelijke gebieden..$^{1-4}$ Deze groepen hebben vaker lagere taal- en gezondheidsvaardigheden die een rol spelen bij de perceptie van gezondheidsrisico's en gezondheidsgedrag. ${ }^{5}$ Naast deze basisvaardigheden speelt een taboe op de diagnose kanker in cultureel, religieus en/of sociaal opzicht mogelijk een rol. Het kan ook zijn dat het kankerrisico onder invloed van genetische, culturele en voedings- of contextfactoren bij deze groepen anders is.

Daarnaast zijn de drie oncologische BVO's alle op een verschillende manier georganiseerd, waardoor de huisarts steeds een andere rol heeft. Die rol is bovendien aan verandering onderhevig en lijkt steeds beperkter te worden. ${ }^{6,7}$

Gezien de unieke, gevarieerde samenstelling van de bevolking van Den Haag leent deze stad zich er bij uitstek voor om de determinanten van deelname en niet-deelname bij de screeningsonderzoeken goed in beeld te krijgen. De onderzoekers zullen de deelname van de geïdentificeerde subgroepen vergelijken, alsmede de kans op de betreffende maligniteiten. Het langetermijndoel is om een bijdrage te leveren aan de optimalisatie van de huidige bevolkingsonderzoeken. Hiervoor zullen de onderzoekers vaststellen wat er nodig is om tot een goed geïnformeerde keuze te komen en zullen zij kijken naar de geschikte rol van én voor de huisarts. Het onderzoek loopt van 2018 tot 2024. De eerste resultaten worden eind 2018 verwacht. $=$

\section{LITERATUUR}

1. Bevolkingsonderzoek Zuid-West. Jaarverslag 2016.

2. Aarts MJ, Voogd AC, Duijm LEM, Coebergh JWW, Louwman WJ. Socioeconomic inequalities in attending the mass screening for breast cancer in the south of the Netherlands-associations

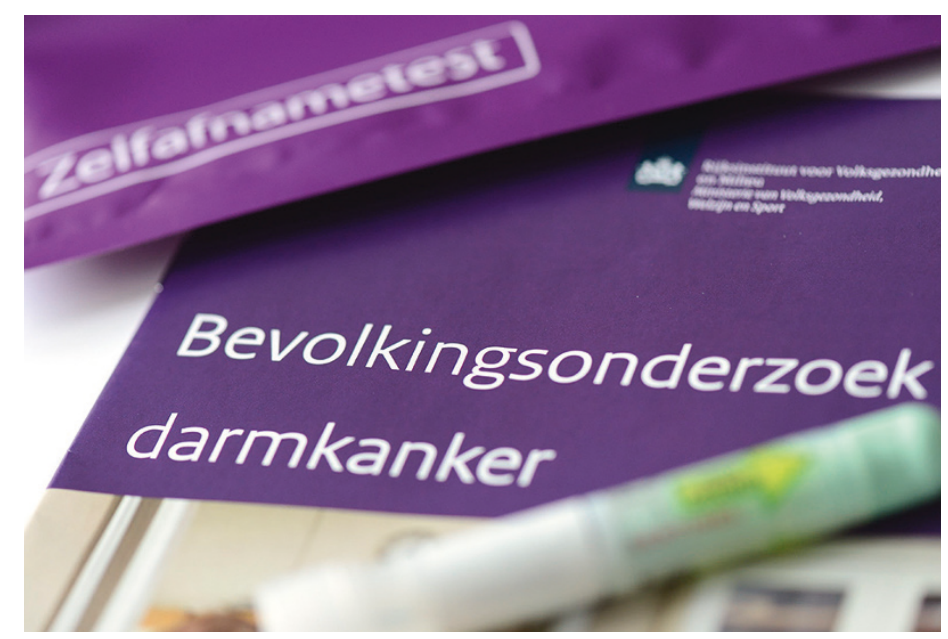

Lage deelname aan oncologisch bevolkingsonderzoek komt vooral voor bij lage SES-groepen, niet-westerse allochtonen en inwoners van stedelijke gebieden.

Foto: ANP Foto

with stage at diagnosis and survival. Breast Cancer Res Treat 2011;128:517-25. DOI: 10.1007/s10549-011-1363-z.

3. Bosgraaf RP, Siebers AG, De Hullu JA, Massuger LFAG, Bulten J, Bekkers RLM, et al. The current position and the future perspectives of cervical cancer screening. Expert Review of Anticancer Therapy 2014;14:75-92. https://doi.org/10.1586/14737140.2014.8 56273.

4. Deutekom M, Rijn A, Dekker E, Blaauwgeers H, Stronks K, Fockens $\mathrm{P}$, et al. Uptake of faecal occult blood test colorectal cancer screening by different ethnic groups in the Netherlands. Eur J Public Health 2009;19:400-2. DOI: 10.1093/eurpub/ckp051.

5. Pharos. Factsheet Laaggeletterdheid en beperkte gezondheidsvaardigheden. Utrecht: Pharos, 2016.

6. RIVM. Bevolkingsonderzoek baarmoederhalskanker: professionals. Vernieuwd bevolkingsonderzoek: wat is er anders? Bilthoven: RIVM, 2016.

7. Van Haaren KMA, Ballieux MJP. NHG-Praktijkhandleiding bevolkingsonderzoek darmkanker. De organisatie en uitvoering van het bevolkingsonderzoek darmkanker in de huisartsenpraktijk. Utrecht: NHG, 2017. 